CZASOPISMO INŻYNIERII LĄDOWEJ, ŚRODOWISKA I ARCHITEKTURY JOURNAL OF CIVIL ENGINEERING, ENVIRONMENT AND ARCHITECTURE

JCEEA, t. XXXIII, z. 63 (4/16), październik-grudzień 2016, s. 383-390

\author{
Bożena ORLIK-KOŻDOŃ ${ }^{1}$ \\ Agnieszka SZYMANOWSKA-GWIŻD $\dot{Z}^{2}$ \\ Pawel KRAUSE ${ }^{3}$ \\ Tomasz STEIDL ${ }^{4}$
}

\title{
WYBRANE ASPEKTY STANU OCHRONY CIEPLNEJ BUDYNKU PLUSENERGETYCZNEGO "P-E-H"
}

\begin{abstract}
Obniżanie zużycia energii w budynkach doprowadziło do coraz powszechniejszego osiągania standardów budynków energetycznych i pasywnych, w których zapotrzebowanie na ciepło wynosi od 15 do $80 \mathrm{kWh} / \mathrm{m}^{2}$. Poprawa rozwiązań w zakresie stanu ochrony cieplnej przegród zewnętrznych oraz technologii pozyskujących energię doprowadziło do pojawienia się budynków zeroenergetycznych. Autorzy podjęli próbę opisu i ocenę wybranych rozwiązań budynku plusenergetycznego. Celem opracowania jest ocena rozwiązań w zakresie ochrony cieplnej wybranych przegród zewnętrznych budynku o obniżonym zużyciu energii. Przedmiotowy budynek został zrealizowany w technologii lekkiego szkieletu drewnianego. Przegrody zewnętrzne pełne (ściana, stropodach, podłoga na gruncie) charakteryzują się bardzo wysokim oporem cieplnym. Aby uzyskać niską wartość współczynnika przenikania ciepła zastosowano izolację termiczną typu VIP. W budynku zamontowano stolarkę okienną o zróżnicowanej izolacyjności termicznej. W celu zwiększenia akumulacyjności cieplnej wykorzystano materiały zmienno-fazowe. W zrealizowanym obiekcie wykorzystano zarówno pasywne jak i aktywne systemy pozyskiwania energii. Konwersja promieniowania słonecznego na energię elektryczną była możliwa poprzez zróżnicowane rodzaje ogniw PV.
\end{abstract}

Słowa kluczowe: izolacja próżniowa, mostki termiczne, opór cieplny, izolacyjność termiczna

\footnotetext{
1 Autor do korespondencji / corresponding author: Bożena Orlik-Kożdoń, Politechnika Śląska, Katedra Budownictwa Ogólnego i Fizyki Budowli, ul. Akademicka 5, 44-100 Gliwice, tel. 32237 2303; Bozena.Orlik@polsl.pl

2 Agnieszka Szymanowska-Gwiżdż; Politechnika Śląska, Katedra Budownictwa Ogólnego i Fizyki Budowli, ul.Akademicka 5, 44-100 Gliwice, tel. 32 237 2303; Agnieszka.Szymanowska-Gwizdz@polsl.pl

3 Paweł Krause; Politechnika Śląska, Katedra Budownictwa Ogólnego i Fizyki Budowli, ul. Akademicka 5, 44-100 Gliwice, tel. 32237 2303; Pawel.Krause@polsl.pl

4 Tomasz Steidl; Politechnika Śląska, Katedra Budownictwa Ogólnego i Fizyki Budowli, ul. Akademicka 5, 44-100 Gliwice, tel. 32237 2303; Tomasz.Steidl@ polsl.pl
} 


\section{Wprowadzenie}

Od lat 90-tych XX w. coraz mocniej rozwija się budownictwo ograniczające zużycie energii na etapie użytkowania budynków. Pierwsze realizacje dotyczyły budynków energooszczędnych i niskoenergetycznych. Tego typu budynki charakteryzowały się rocznym zużyciem energii na cele ogrzewania i wentylacji na poziomie około $50-80 \mathrm{kWh} / \mathrm{m}^{2}$. Jeden z przykładowych budynków tego typu został szczegółowo omówiony w [5]. Kolejnym krokiem było pojawienie się budynków zużywających około $30 \mathrm{kWh} / \mathrm{m}^{2}$. Dalsze obniżanie zużycia energii prowadziło do osiągnięcia standardów tzw. budynków pasywnych, w których zapotrzebowanie na ciepło nie przekracza $15 \mathrm{kWh} /\left(\mathrm{m}^{2} \mathrm{rok}\right)$. Ciągłe doskonalenie rozwiązań pozyskujących energię doprowadziło do pojawienia się budynków zeroenergetycznych. Tego typu obiekty $\mathrm{w}$ wielu przypadkach nie wymagają doprowadzenia konwencjonalnych źródeł energii. Ze względu na rozwiązania materiałowo-instalacyjne takie budynki te można traktować jako samowystarczalne. W strefie klimatycznej Europy środkowo-wschodniej występuje problem związany z nadwyżką energii w okresach letnich. Przy właściwie zbilansowanym budynku, zapewniającym pokrycie zapotrzebowania na energię $\mathrm{w}$ okresach zimowych, w przypadku rozwiązań budynków bazujących na ogniwach fotowoltaicznych, latem występują nadwyżki produkowanej energii elektrycznej. Można wtedy mówić o budynkach plusenergetycznych $[3,4,6]$. Samo pojęcie budynku plusenergetycznego, podobnie jak budynków pasywnych czy zeroenergetycznych, nie jest zdefiniowane w sposób jednoznaczny. Nie definiuje tego żaden akt prawny.

Jednym z najistotniejszych zadań w sektorze budownictwa jest powszechne wykorzystanie odnawialnych źródeł energii. W roku 2007 renomowany konkurs Solar Decathlon odbywający się w Waszyngtonie wygrała niemiecka uczelnia TU Darmstadt. Autorzy niniejszej publikacji podjęli próbę przedstawienia dobrych praktyk oraz przeprowadzenia oceny stanu ochrony cieplnej wybranych rozwiązań na przykładzie budynku Plus-Energie-Haus (P-E-H), który jest rozwinięciem budynku konkursowego (rys. 1). Przedmiotowy budynek powstał jako konsekwencja inicjatywy badawczej „Budownictwo Przyszłości - Budownictwo zorientowane na innowacyjność" niemieckiego ministerstwa BMVBS [1]. Celem niniejszego projektu było wzmożenie konkurencyjności niemieckich firm z branży budowlanej. W wyniku podjętych działań zrealizowano demonstracyjny obiekt. Jednym z głównych założeń interdyscyplinarnego projektu, obok opracowania modelowego budynku, było rozpropagowanie nowych technologii wraz z transferem wyników.

\section{Rozwiązania materiałowo-konstrukcyjne}

Główna koncepcja budynku P-E-H opiera się na minimalizacji zapotrzebowania na energię oraz optymalizacji zapotrzebowania na cele ogrzewania, chło- 
dzenia, wentylacji i oświetlenia. Prototypowy budynek został zrealizowany, jako innowacyjny budynek mieszkalny, przez architektów i inżynierów uczelni TU Darmstadt. Budynek został zaprojektowany w oparciu o kryteria budynku pasywnego. Dotyczy to w szczególności zwrócenia uwagi na przegrzewanie pomieszczeń latem - elementy zacieniające oraz równoczesne wykorzystanie zysków słonecznych w okresach zimowych. Wykorzystanie materiałów zmiennofazowych umożliwia przesunięcie czasowe ogrzewania i wychładzania pomieszczeń w ciągu dnia. W budynku wykorzystano pasywne i aktywne systemy pozyskiwania energii. Ze względu na fakt, iż budynek produkuje więcej energii niż zużywa na cele normalnej eksploatacji, nadwyżka energetyczna energii elektrycznej wykorzystywana jest do celów ładowania samochodów z napędem elektrycznym. Pozostała niewykorzystana część energii jest sprzedawana. Budynek wykonano jako częściowo prefabrykowany w konstrukcji szkieletu drewnianego. Ze względu na wymóg wysokiej efektywności energetycznej, izolacyjność termiczna przegród zewnętrznych, w tym ścian, podłogi oraz dachu, musiała spełniać zaostrzone wymogi w zakresie izolacyjności termicznej.

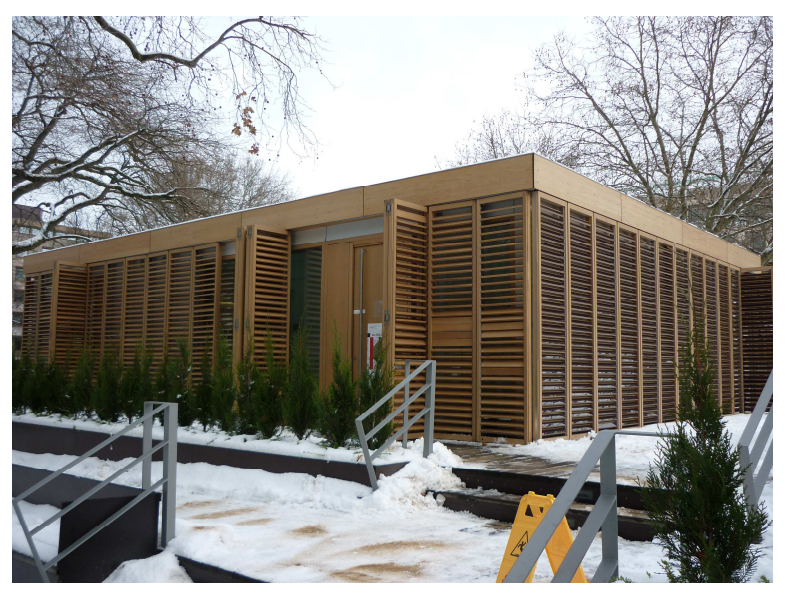

Rys. 1. Widok ogólny budynku Plus-Energie-Haus

Fig. 1. General view of the building Plus-Energy-Haus

Ściana zewnętrzna została wykonana jako szkieletowa drewniana. Konstrukcja nośna wykonana z elementów drewnianych o przekroju $6 \times 10 \mathrm{~cm}$. Ze względu na ograniczoną akumulacyjność cieplną budynków realizowanych w konstrukcji szkieletowej od strony wewnętrznej zastosowano płyty z domieszką materiału zmiennofazowego PCM gr. $1,5 \mathrm{~cm}$ oraz pod nimi płyty gipsowo-kartonowe, mocowane na łatach $2 \times 7 \mathrm{~cm}$. Pomiędzy elementami konstrukcyjnymi zastosowano wełnę mineralną gr. $10 \mathrm{~cm}$. Od strony zewnętrznej do konstrukcji drewnianej zamocowano płyty OSB gr. $1,8 \mathrm{~cm}$ oraz izolację paroszczelną. Główną izolację termiczną wykonano w postaci paneli izolacji próżnio- 
wej VIP. Zastosowano dwie warstwy izolacji VIP o sumarycznej grubości $6 \mathrm{~cm}$ (rys. 2). Ze względu na konieczność mocowania mechanicznego pozostałych elementów elewacyjnych izolację próżniową mocowano przy pomocy łat krzyżowych wykonanych z purenitu. Warstwę zewnętrzną stanowią elementy żaluzji drewnianych ze zintegrowanymi ogniwami fotowoltaicznymi. Elementy te zamocowano do płyt włókno-cementowych gr. $0,8 \mathrm{~cm}$, które zostały zamocowane do łat nośnych $4 \times 7 \mathrm{~cm}$. Od strony północnej zlokalizowano żaluzje zewnętrzne bez ogniw PV. Budynek przykrywa stropodach pełny (rys. 3), na bazie drewnianej belkowej konstrukcji nośnej o wymiarach przekroju poprzecznego $6 \times 15 \mathrm{~cm}$. Pomiędzy belkami stropowymi układanymi w rozstawach $60 \mathrm{~cm}$ wbudowano wełnę mineralną gr. $15 \mathrm{~cm}$. Podobnie jak w przypadku ścian zewnętrznych ze względu na poprawę akumulacyjności cieplnej na stropie zamocowano płyty zmiennofazowe PCM gr. $1,5 \mathrm{~cm}$, mocowane na drewnianych łatach $3 \times 7 \mathrm{~cm}$. Materiał zmiennofazowy PCM na ścianach oraz na suficie zwiększa akumulacyjność cieplną lekkich przegród wykonanych w konstrukcji drewnianej zapewniając, obok stateczności cieplnej, odpowiedni mikroklimat pomieszczeń. Od strony zewnętrznej do stropu drewnianego zamocowano płyty OSB gr. 1,8 cm. Główną izolacją termiczną wykonano w postaci paneli izolacji próżniowej VIP. Zastosowano dwie warstwy izolacji VIP o sumarycznej grubości $6 \mathrm{~cm}$. Na izolacji próżniowej ułożono płyty cementowe gr. $2,2 \mathrm{~cm}$, na płytach izolację termiczną w postaci wełny mineralnej gr. $12-18 \mathrm{~cm}$, kształtującą dodatkowo spadek pokrycia dachowego. Pokrycie dachowe wykonano w postaci foli Rhepanol. Na warstwie pokrycia zlokalizowano elementy instalacji fotowoltaicznej i solarnej. Podłoga na gruncie została wykonana jako podłoga podniesiona. Pomiędzy legarami o wysokości $40 \mathrm{~cm}$ zastosowano wdmuchiwaną izolację termiczną na bazie celulozy. Posadzkę stanowiła płyta cementowa Duripanel gr. 2,2 cm. Przeszklenie budynku pełni istotną rolę w przypadku pasywnych zysków cieplnych oraz oświetlenia wnętrz. Pomimo znacznej powierzchni przeszklenia, ograniczono straty ciepła przez stolarkę okienną poprzez zastosowanie drewnianej stolarki okiennej o wysokiej izolacyjności termicznej. Wszystkie okna wykonano jako drewniane. Budynek P-E-H posiada trzy różne rodzaje ogniw PV. Główny zestaw ogniw PV zlokalizowany jest na dachu. Ze względu na architekturę budyn$\mathrm{ku}$ oraz problematykę wzajemnego zacienienia moduły zostały zlokalizowane prawie płasko (nachylenie ok. $2^{\circ}$ ). $\mathrm{Z}$ tego względu ogniwa PV wytwarzają ok. $8 \%$ mniej energii w ciągu roku, w porównaniu z ilością energii otrzymywaną dla optymalnego kąta nachylenia dachu. Ze względu na płaskie ułożenie ogniw istnieje jednakże możliwość zrównoważenia tej straty poprzez zwiększoną liczbę ogniw PV. Oprócz modułów dachowych ogniwa PV zlokalizowane są także jako żaluzje ścienne. Dla uzyskania jak najlepszego efektu energetycznego żaluzje są ruchome oraz sterowane poprzez komputer w celu uzyskania optymalnego nachylenia względem Słońca. Trzeci rodzaj ogniw PV zlokalizowany jest nad werandą, stanowiąc jej dodatkowe zadaszenie. Sumaryczna moc ogniw PV wynosi ok. $15 \mathrm{kWp}$. 


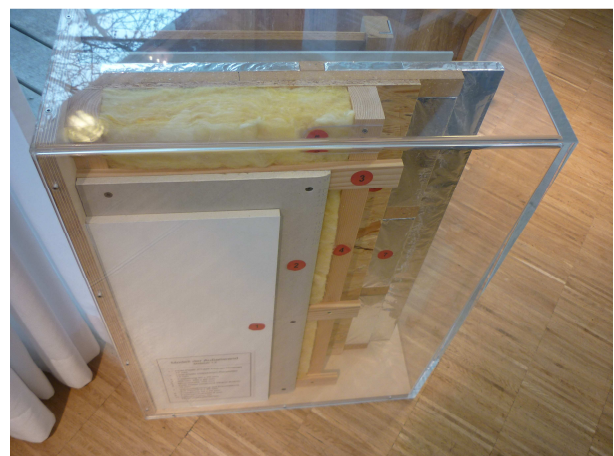

Rys. 2. Model ściany zewnętrznej Plus-EnergieHaus

Fig. 2. Model of outer wall Plus-Energy-Haus

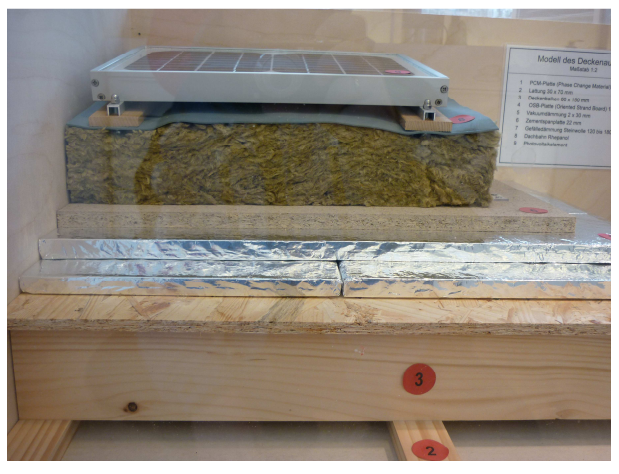

Rys. 3. Model stropodachu pełnego Plus-EnergieHaus

Fig. 3. Model of roof Plus-Energy-Haus

Podstawową koncepcją budynku było ograniczenie strat ciepła przez obudowę oraz efektywne wytworzenie energii. Zostało to osiągnięte poprzez wykorzystanie pasywnych i aktywnych systemów pozyskiwania energii. Odpowiednio dobrana kombinacja poszczególnych subsystemów jest bardzo ważna z punktu widzenia budynku jako całości. Ogrzewanie i wentylację budynku realizowano przy pomocy urządzenia typu kombi w postaci zintegrowanej powietrznej pompy ciepła z centralą wentylacyjną z rekuperacją powietrza. Dodatkowym ciekawym rozwiązaniem wpływającym na poprawę mikroklimatu pomieszczeń $\mathrm{w}$ okresach letnich jest pasywny system chłodzenia nocnego z wykorzystaniem materiału zmiennofazowego PCM.

\section{Stan ochrony cieplnej przegród zewnętrznych}

Rozwiązania projektowe, w zakresie ochrony cieplnej, zostaną omówione na przykładzie fragmentów dokumentacji projektowej budynku. Wszystkie obliczenia izolacyjności termicznej przegród wykonywano wykorzystując obliczeniowe współczynniki przewodzenia ciepła $\lambda$ materiałów oraz wartości deklarowane przez producentów. Obliczeniowy współczynnik przewodzenia ciepła dla ścian zewnętrznych wynosi $\mathrm{U}=0,1 \mathrm{~W} /\left(\mathrm{m}^{2} \mathrm{~K}\right)$. Analogiczna wartość współczynnika przenikania ciepła dotyczy stropodachu pełnego i wynosi $\mathrm{U}=0,1 \mathrm{~W} /\left(\mathrm{m}^{2} \mathrm{~K}\right)$. Współczynnik przenikania ciepła podłogi na gruncie przy izolacji termicznej grubości $40 \mathrm{~cm}$ pomiędzy legarami wynosi $\mathrm{U}=0,11 \mathrm{~W} /\left(\mathrm{m}^{2} \mathrm{~K}\right)$. Przeszklenie fasady północnej zrealizowano za pomocą zestawu czteroszybowego o współczynniku przenikania ciepła $\mathrm{U}_{\mathrm{g}}=0,32 \mathrm{~W} /\left(\mathrm{m}^{2} \mathrm{~K}\right)$ i współczynniku $\mathrm{g}=37 \%$. Współczynnik przenikania ciepła dla okna wynosi $\mathrm{U}_{\mathrm{w}}=0,6 \mathrm{~W} /\left(\mathrm{m}^{2} \mathrm{~K}\right)$. W przypadku strony południowej w oknach zamontowano wkłady trójszybowe. Współczynnik przenikania ciepła $\mathrm{U}_{\mathrm{g}}=0,56 \mathrm{~W} /\left(\mathrm{m}^{2} \mathrm{~K}\right), \mathrm{U}_{\mathrm{w}}=0,70 \mathrm{~W} /\left(\mathrm{m}^{2} \mathrm{~K}\right)$. Drzwi zewnętrzne zostały wykonane jako drewniane $\mathrm{z}$ rdzeniem termoizolacyjnym $\mathrm{z}$ pa- 
neli VIP, o współczynniku przenikania ciepłą $\mathrm{U}=0,60 \mathrm{~W} /\left(\mathrm{m}^{2} \mathrm{~K}\right)$. Analiza rozwiązań projektowych, w odniesieniu do mostków termicznych w miejscach połączeń poszczególnych przegród budowlanych, wspomagana była obliczeniami numerycznymi w programie Therm 7.4. Obliczona wartość liniowego współczynnika przenikania ciepła dla połączenia stropodachu pełnego ze ścianą zewnętrzną wynosi $\psi_{\mathrm{i}}=0,0076 \mathrm{~W} / \mathrm{mK}$.
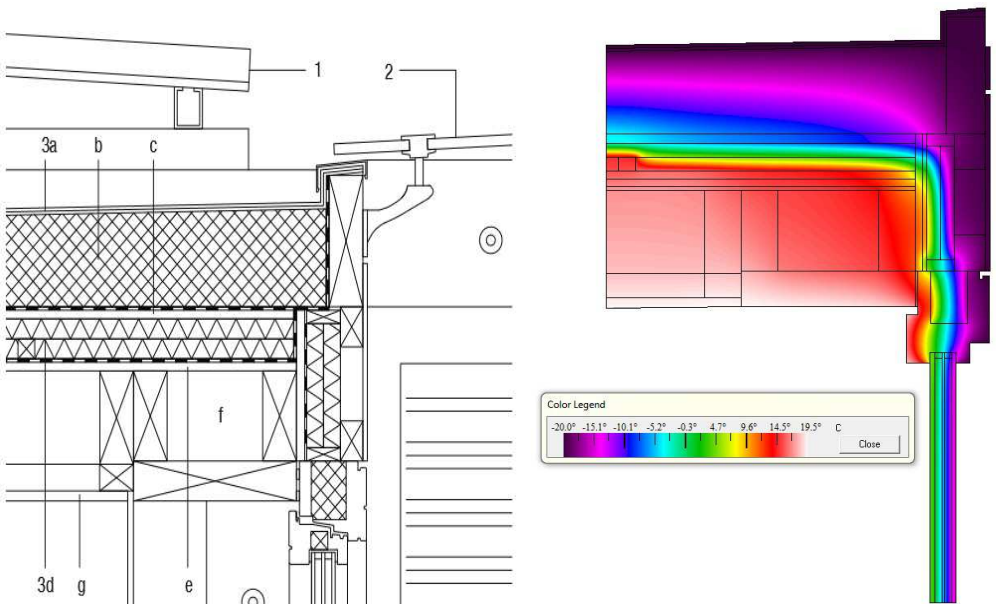

Rys. 4. Szczegół połączenia stropodachu pełnego ze ścianą zewnętrzną

Fig. 4. Detail of the connection of roof and wall

Analizując rozwiązania materiałowo-konstrukcyjne połączenia stolarki okiennej ze ścianą zewnętrzną należy zauważyć, iż w przypadku wykonywania budynków w technologii lekkiego szkieletu drewnianego stolarka okienna jest mocowana do drewnianego nadproża. Jest to szczegółowo pokazane na rys. 4. W celu poprawy izolacyjności termicznej tego fragmentu budynku projektanci zaproponowali zastosowanie sufitu podwieszanego z dodatkową warstwą przestrzeni powietrznej pomiędzy sufitem a stropodachem. W obrębie połączenia sufitu ze ścianą przy stolarce okiennej zastosowano dodatkowo element drewniany gr. $8 \mathrm{~cm}$. Spowodowało to, że temperatura na wewnętrznej powierzchni naroża stropodach-okno wynosi $16,3^{\circ} \mathrm{C}$ (dla obliczeniowej temperatury wewnętrznej $+20^{\circ} \mathrm{C}$ i temperatury zewnętrznej na poziomie $-20^{\circ} \mathrm{C}$ ). Bez zastosowania dodatkowego drewnianego elementu sufitu podwieszanego temperatura na styku stolarki okiennej i ściany wynosi ok. $10,5^{\circ} \mathrm{C}$. Tego typu wartości związane są z zastosowaniem rozwiązań projektowych elewacji podwieszonej w postaci płyt włókno-cementowych, mocowanych do drewnianego rusztu. W przypadku wykonania ocieplenia w systemie ETICS doprowadziłoby to do istotnego podniesienia temperatury na wewnętrznej powierzchni przegrody. Rozkład temperatury dla omawianego detalu projektowego przedstawiono na rys. 5. 


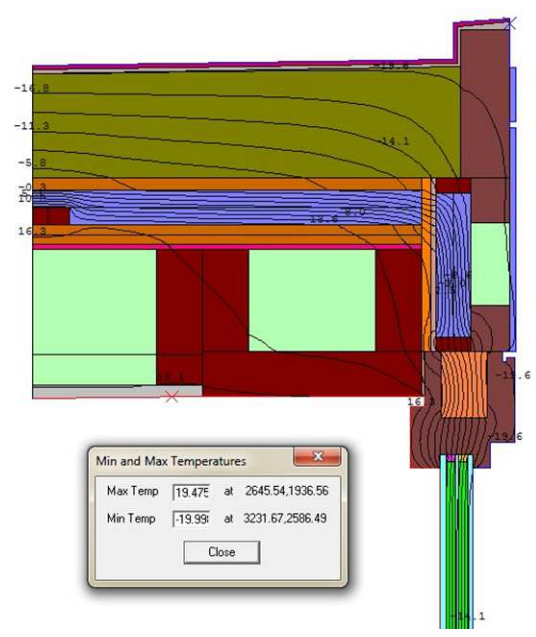

Rys. 5. Rozkład temperatury dla detalu połączenia stropodachu ze ścianą zewnętrzną

Fig. 5. Temperature distribution in detail of the connection of roof and wall

\section{Podsumowanie}

Przedstawiony w artykule przykładowy budynek plusenergetyczny P-E-H jest interesującą koncepcją rozwiązania obiektu o ekstremalnie niskim zapotrzebowaniu na energię, który wytwarza więcej energii niż wymagają tego potrzeby eksploatacyjne. Na szczególną uwagę zasługują rozwiązania wysokoefektywnych energetycznie przegród zewnętrznych, w których zastosowano izolację cieplną nowej generacji typu VIP. Ze względu na fakt, że prezentowany obiekt zrealizowano $\mathrm{w}$ technologii szkieletu drewnianego, koniecznym było zastosowanie materiałów zmiennofazowych, zwiększających akumulacyjność cieplną. Pomimo, iż rozwiązania wybranych detali projektowych wskazywały w wybranych miejscach na potencjalne problemy w zakresie mostków termicznych, autorom projektu udało się w sposób optymalny zaprojektować opisywany budynek z punktu widzenia jego stanu ochrony cieplnej.

\section{Literatura}

[1] Bauen für die Zukunft. Plus-Energie-Haus des Bundesministeriums für Verkehr, Bau und Stadtentwicklung Ein mobiler Ausstellungs und Forschungspavillon Technische Informationen und Details. BMVBS. Berlin 2010.

[2] Bointner R. i in. Gebäude maximaler Energieeffizienz mit integrierter erneuerbarer Energieerschließung. BMViT. Berlin 2012.

[3] Hegger M. Solar Decathlon 2007 - Prototype Home 2015. TU Darmstadt. Zukunft bauen. Das Magazin der Forschungsinitiative Zukunft Bau. Berlin 2009. 
[4] Hernandez P., Kenny P. From Net Energy to Zero Energy Buildings: Defining Life Cycle Zero Energy Buildings (LC-ZEB). Energy and Buildings, 42 (2010), pp. 815-821.

[5] Krause P. Steidl T. Racjonalne zużycie energii na przykładzie budynku "NEH" w Zittau. Innowacyjne idee i technologie dla budownictwa. Pierwsza Międzynarodowa Konferencja Energii Słonecznej i Budownictwa Ekologicznego, Solina, 17-20 maja 2006. Pod red. L. Lichołai. Oficyna Wydaw. Politechniki Rzeszowskiej, 2006.

[6] Marszal A.J., Heiselberg P., Bourrelle J.S., Musall E., Voss K., Sartori I., Napolitano A. Zero Energy Building - A Review of Definitions and Calculation Methodologies. Energy and Buildings, 43 (2011), pp. 971-979.

[7] Sartori I., Napolitano A., Voss K. Net Zero Energy Buildings: A Consistent Definition Framework Energy and Buildings, 48 (2012), pp. 220-232.

[8] Voss K., Mussal E., Lichtmess M. From Low-Energy to Net Zero-Energy Buildings: Status And Perspectives. Journal of Green Building, 6 (2011), pp. 46-57.

\section{THERMAL PROTECTION OF PLUSENERGY HOUSE "P-E-H" - CASE STUDY}

\section{S u m m a r y}

The authors attempted description and evaluation of the solutions adopted plusenergy building P-E-H. The objective is to evaluate solutions in the field of heat protection of selected external partitions of the building with reduced energy consumption. The building was realized in light wooden skeleton. Stay applied a highly thermal insulation type VIP, as well as a number of installation solutions for obtaining efficient energy.

The building was realized in light wooden skeleton. Baffles full outer (wall, ceiling, floor on the ground) are characterized by very high heat resistance. For low value of heat transfer coefficient applied thermal insulation type VIP. In a building fitted woodwork window at varying thermal insulation. In order to increase the heat accumulation materials variation-phase. In the completed object uses both passive and active energy. Conversion of solar radiation into electricity was made possible through various types of PV cells.

Keywords: plusenergy building, vacuum insulation, thermal insulation

DOI: $10.7862 / \mathrm{rb} .2016 .283$

Przestano do redakcji: $30.06 .2016 r$.

Przyjęto do druku: 20.12.2016 r. 